\title{
Fluid filtration and dye leakage testing of Resilon/Epiphany and guttapercha/Pulp Canal Sealer root canal fillings
}

\author{
Gabriele Conte $^{1}$, Manuele Mancini ${ }^{1}$, Loredana Cerroni ${ }^{1}$, Marco Costantini ${ }^{2}$, Luigi Cianconi ${ }^{2}$ \\ ${ }^{1}$ Department of Dental Materials, University of Rome "Tor Vergata”, Rome, Italy \\ ${ }^{2}$ Department of Operative Dentistry and Endodontics, University of Rome "Tor Vergata", Rome, Italy \\ Email: gabriele-conte@libero.it
}

Received 9 September 2013; revised 25 October 2013; accepted 7 November 2013

Copyright (C) 2013 Gabriele Conte et al. This is an open access article distributed under the Creative Commons Attribution License, which permits unrestricted use, distribution, and reproduction in any medium, provided the original work is properly cited.

\begin{abstract}
The aim of the present study was to compare sealing abilities of Resilon/Epiphany (R/E) with those of guttapercha and Kerr Pulp Canal Sealer EWT (GP/PCS). 50 single rooted teeth were randomly divided into 2 groups $(n=22)(R / E ; G P / P C S)$, and 2 control groups $(\mathrm{n}=3)$ (Positive, Negative). Fluid flow rate through the filled roots was measured using a fluid filtration device. The same specimens were immersed in a $2 \%$ Methylen Blue Solution. Roots were embedded in clear epoxy resin and cross sectionet at $1 \mathrm{~mm}$ intervals along the length of the root. Circumferential dye penetration was evaluated at $40 \times$ magnification. Fluid filtration of teeth obturated with the $R / E$ system $\left(0.085[0.057,0.113] \mu \mathrm{L} \cdot \mathrm{min}^{-1}\right)$, and dye penetration test showed no statistically significant difference compared to those obturated with GP/PCS $(0.113[0.057$, $\left.0.141] \mu \mathrm{L} \cdot \mathrm{min}^{-1}\right)$. Within the limits of the present study, there is no statistically significant difference between $R / E$ and GP/PCS sealing abilities.
\end{abstract}

Keywords: Resilon; Epiphany; Fluid Filtration; Root Canal Filling Materials; Dye Leakage

\section{INTRODUCTION}

The aim of endodontic treatment is to prevent or heal infective and inflammatory processes in periradicular structures. Apical periodontitis is mainly caused by bacteria and their by-products [1-3]. Disinfection of the root canal space is achieved through the use of various mechanical shaping techniques and chemical irrigants [4-7]. However, a complete eradication of endodontic pathogens is not always possible [4]. Thus, a three-dimensional sealing of the entire root canal system is required to entomb any surviving microorganism which could cause or sustain periradicular pathosis [8].
Techniques using a combination of gutta-percha cones and a sealer are considered the gold standard in root canal obturation. Although good clinical results for many years, some in vitro and in vivo studies have demonstrated that they fail to achieve a complete root canal seal [9-12]. The presence of microleakage is attributed to the lack of an effective bond at both the sealer/dentin and sealer/gutta-percha interfaces [13,14].

Adhesive resins are commonly employed in operative dentistry to bond resin-based restorative materials to tooth structures. In the past decade, dentin adhesives have been used in attempts to bond to intraradicular dentin and have been shown to reduce apical and coronal leakage $[15,16]$.

In that perspective, a syntetic thermoplastic polymerbased root canal filling material (Resilon ${ }^{\mathrm{TM}}$, Resilon Research LLC, Madison, CT), has been developed. This root canal filling material behaves like gutta-percha, has similar handling properties, and may be softened with heat or dissolved in solvents such as chloroform. Based on polycaprolactone, a biodegradable aliphatic polyester [17], Resilon contains bioactive glass, dimethacrylates, bismuth oxychloride and barium sulfate [18]. As it contains dimethacrylates, it is bondable to a variety of methacrylate-resin-based sealers such as Epiphany (Pentron Clinical Technologies, Wallingford, CT), Real Seal (SybronEndo, Orange, CA), and Next (Heraeus-Kulzer, Armonk, NY). These dual-curable dental resin composite sealers are bonded to dentinal walls using a corresponding self-etching primer. By bonding to both the obturating core material and the dentinal walls [19], Epiphany sealer claims to be more resistant to bacterial leakage in vitro [19] and in vivo [20] and may help to reinforce the teeth lessening the chance of vertical root fracture [21]. These favourable results require experimental confirmation.

Several methods have been employed to evaluate the sealing properties of root canal filling materials, includ- 
ing dye penetration [22], bacterial leakage [23], radiolabeled tracer penetration [24], glucose penetration [25], and electrochemical methods [26]. As none of the abovementioned methods alone completely cover the complex nature of root canal sealing, all these techniques are valuable to higher or lower extent [27-29]. However, a universally accepted golden standard for the evaluation of leakage does not yet exist.

The aim of the present study was to use the fluid filtration and dye penetration methods to compare the sealing ability of gutta-percha combined with a zinc-oxide/ eugenol-based root canal sealer (Pulp Canal Sealer EWT-Kerr Sybron Dental Specialities, Romulus, USA) to that of Resilon combined with Epiphany Root Canal Sealer.

\section{MATERIALS \& METHODS}

Fifty single-rooted human teeth extracted for periodontal reasons were used after the patient's informed consent. The Ethical Committee of the Rome Tor Vergata University approved the research protocol. Each tooth was carefully cleaned with curettes to remove any calculus or soft tissue debris and stored in $0.5 \%$ Chloramine $\mathrm{T}$ aqueous solution until use. The crowns were sectioned below the cementum-enamel junction with a low speed diamond saw (Isomet, Buehler, Lake Bluff, NY) so that the length of the remaining root was approximately 15 $\mathrm{mm}$. The working length was visually established by subtracting $0.5 \mathrm{~mm}$ from the length of a size $15 \mathrm{~K}$-type file (Maillefer, Baillaguets, Switzerland) at the apical foramen. The coronal third was prepared using ISO size 3 and 4 Gates Glidden drills (Maillefer, Ballaigues, Switzerland).

All teeth were instrumented with a crown-down technique using a set of ProTaper Universal rotary instruments (Dentsply Maillefer, Ballaigues, Switzerland) as follows: the ProTaper Sx instrument was advanced into the root canal to just short of the working length. The other files were used in the following sequence, and all were advanced to working length: S1, S2, F1, F2 and F3. The root canals were then further instrumented with GT System (Dentsply Maillefer, Ballaigues, Switzerland) rotary files to obtain an ISO size \#40, 0.10 taper apical preparation. Apical preparation to size 40 was chosen to standardize apical diameters between the specimens and to improve the apical cleanliness. RC Prep (Premier, Plymouth, PA) served as a lubricant during the cleaning and shaping procedure.

A $1 \mathrm{ml}$ aliquot of $5.25 \% \mathrm{NaOCl}$ warmed to $37^{\circ} \mathrm{C}$ was delivered between each instrument with a $30 \mathrm{G}$ endodontic needle (Navitip, Ultradent, UT) $1 \mathrm{~mm}$ short of the working length. The patency of the apical foramen was maintained with a $\# 20 \mathrm{~K}$ file. Finally, the root canals were flushed with $5 \mathrm{~mL}$ of $5.25 \% \mathrm{NaOCl}$ for 5 minutes, $5 \mathrm{~mL}$ of $17 \%$ EDTA for 5 minutes, and $3 \mathrm{~mL}$ of distilled water.

The prepared specimens were then randomly divided into 2 groups of 22 specimens each (Resilon/Epiphany; Guttapercha/Pulp Canal Sealer EWT) with the remaining 6 used as controls.

\subsection{Resilon/Epiphany Group $(\mathrm{R} / \mathrm{E})(\mathrm{n}=\mathbf{2 2})$}

After instrumentation, root canals were dried with sterile paper points (Dentsply Maillefer) and then a self-etching primer (Epiphany Primer; Pentron Clinical Technologies) was placed into the canal with a thin needle. Excess primer was then removed with paper points (Dentsply Maillefer). Roots were filled with a master cone of Resilon and Epiphany sealer using the continuous wave of condensation technique (Elements Obturation Unit, Sybron Endo Corporation, Orange, CA, USA) and a backfill with thermoplasticized Resilon injection was performed with the Extruder Handpiece (Elements Obturation Unit). The coronal $5 \mathrm{~mm}$ of each root canal were not filled.

The roots were then light cured according to the manufacturer's recommendation for 40 seconds using an LED curing unit (Smartlite PS; Dentsply, DeTrey, Konstanz, Germany) to create an immediate coronal seal.

\subsection{Guttapercha/Pulp Canal Sealer EWT Group (GP/PCS) $(\mathrm{n}=22)$}

Root canals were dried with sterile paper points (Dentsply Maillefer). A guttapercha master cone was fitted apically and vertically thermoplasticized using continuous wave of condensation technique (Elements Obturation Unit). A backfill with thermoplasticized guttapercha injection was performed with the Extruder Handpiece (Elements Obturation Unit). Pulp Canal Sealer EWT was used when placing the master cone. The coronal $5 \mathrm{~mm}$ of each root canal were not filled.

\subsection{Positive Control Group $(n=3)$}

The Instrumented root canals were left unfilled.

\subsection{Negative Control Group $(n=3)$}

The Instrumented root canals were left unfilled with the apical thirds sealed with wax and totally covered with three layers of nail polish.

The length and density of the fill for both experimental groups was confirmed using analogic radiography with Kodak Insight xr dental film (Eastman Kodak Company, Rochester, N.Y.).

All 50 roots were covered with two layers of nail varnish except for $2 \mathrm{~mm}$ of the apical and coronal regions, 
wrapped in gauze dampened with sterile saline, and enclosed in sealed tubes stored at $37^{\circ}$ for 7 days to allow the sealer to set [30].

\subsection{Fluid Filtration Test}

The fluid filtration device was built ad hoc by technicians of the Dental materials department of the University of Rome Tor Vergata according to the design proposed by $\mathrm{Wu}$ et al. [31] (Figure 1) The roots from GP/PCS, R/E, negative and positive control group, were mounted on plexiglass blocks with viscous cyanoacrylate cement (Fill-It, American Dental Supply, Easton, PA). The plexiglass blocks were penetrated by 18 gauge stainless steel tubes that permitted water to be introduced into the coronal portion of the roots. The coronal end was connected by polyethylene tubing to a T-tube connector, which joined a microsyringe to the fluid-filled system. The microsyringe was used to introduce a minute air bubble into a glass capillary tube of uniform diameter (25 $\mu 1$ Microcap, Fisher Scientific, Atlanta, GA) equipped with a ruler (Fisher Scientific, Atlanta, GA) to permit accurate measurement of the air-bubble displacement. Leakage was assessed at $3.6 \mathrm{psi}(0.25 \mathrm{~atm})$ [32]. Measurements of fluid movement were performed at 2 minute intervals for $60 \mathrm{~min}$ and averaged. Fluid flow rates (i.e. leakage) were expressed as $\mu \mathrm{L} \cdot \mathrm{min}^{-1}$. The data were analyzed using the Kruskal-Wallis test to compare leakage of the obturated canals. The level of significance was set at 0.05 .

\subsection{Dye Leakage Test}

The specimens were removed from their plexiglass

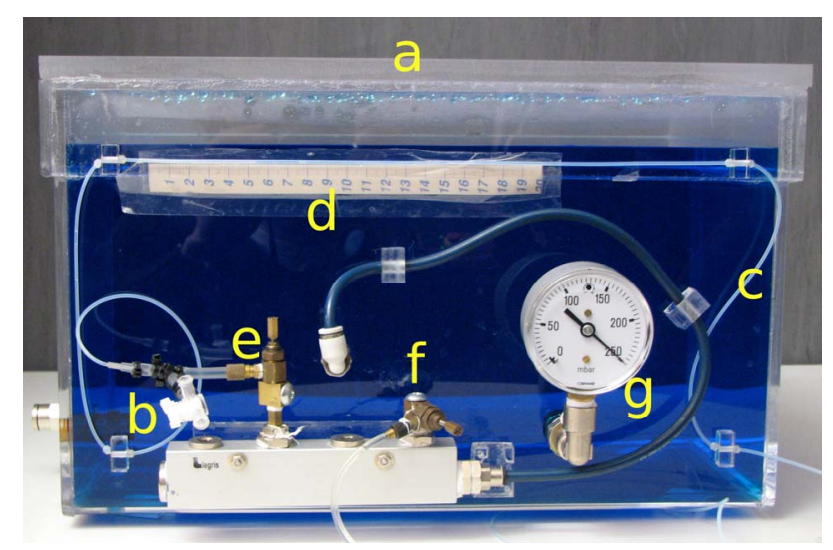

Figure 1. The fluid filtration apparatus realized following the model proposed by Wu et al. (1993) consist of a liquid pressurized (250 mBar) reservoir (a); a micro-syringe to adjust the micro air bubble (b); a micro-capillary tube connected to the specimen (c); a ruler to measure the movement of the micro air bubble (d); a tap to give and remove pressure to the microcapillary tube (e); a tap to adjust the pressure of the reservoir (f) monitorized with a manometer $(\mathrm{g})$. stands and immersed in a neutral-buffered $2 \%$ aqueous solution of methylene blue for $48 \mathrm{~h}$ at $37^{\circ} \mathrm{C}$. The roots were then copiously rinsed with water, dried, and embedded in clear epoxy resin. The teeth were sectioned at 1-millimeter intervals perpendicular to the long axis of the root using a water-cooled low-speed diamond disk (Isomet, Buehler, Lake Bluff, NY) $0.3 \mathrm{~mm}$ thick, resulting in a series of $0.7 \mathrm{~mm}$-thick slices. The bottom surface of each section was identified as the " $n$ " level of the root canal, while the top surface corresponded to the " $n$ " + $0.7 \mathrm{~mm}$ level. The top and bottom surfaces of each section were evaluated by an independent observer under $40 \times$ magnification using a stereomicroscope (Olympus SZ40, Japan) to assess the extension of dye penetration along the root canals at various distances from the apex $(0,0.7,1.0,1.7,2.0,2.7,3.0,3.7,4.0,4.7,5.0,5.7,6.0$, 6.7, 7.0, 7.7, 8.0, 8.7, 9.0, and 9.7 $\mathrm{mm}$ ) (Figure 2).

Scores to describe the degree of circumferential dye penetration (dp) for each surface were assigned as reported in Table 1.

The non-parametric Kruskal-Wallis test was used to compare the medians in the two groups.

\section{RESULTS}

\subsection{Fluid Filtration Test}

The leakage of the negative control group as measured by the fluid filtration model was uniformly zero, and the leakage of the positive control group was immeasurably

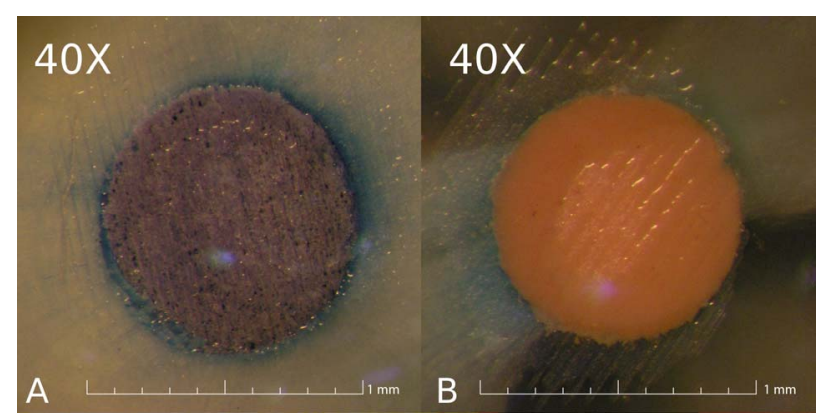

Figure 2. $40 \times$ magnification images of a Resilon/Epiphany specimen (A) showing a score 4 circumferential dye penetration, and a gutta-percha/Pulp Canal Sealer specimens (B) showing a score 1 circumferential dye penetration.

Table 1. Circumferential dye penetration scores.

\begin{tabular}{cc}
\hline Score & Dye Penetration \\
\hline 0 & $0^{\circ}$ \\
1 & $0^{\circ}<\mathrm{dp} \leq 90^{\circ}$ \\
2 & $90^{\circ}<\mathrm{dp} \leq 180^{\circ}$ \\
3 & $180^{\circ}<\mathrm{dp} \leq 270^{\circ}$ \\
4 & $270^{\circ}<\mathrm{dp} \leq 360^{\circ}$ \\
\hline
\end{tabular}


high. This confirmed the reliability of the fluid filtration apparatus.

The median fluid microleakage in the $\mathrm{R} / \mathrm{E}$ group was $0.085[0.057,0.113] \mu \mathrm{L} \cdot \mathrm{min}^{-1}$. The median fluid microleakage in the GP/PCS group was 0.113 [0.057, 0.141] $\mu \mathrm{L} \cdot \min ^{-1}$. Figure 3 summarizes the median linear fluid movement in $\mu \mathrm{L} \cdot \mathrm{min}^{-1}$ for the GP/PCS and R/E groups.

Two of the 22 specimens in the Resilon/Epiphany group experienced no leakage at the end of the experimental period $(60 \mathrm{~min})$, and none of the 22 specimens in the GP/PCS group were leak-free at the end of the experimental period. The $\mathrm{R} / \mathrm{E}$ group leaked less than the GP/PCS group, although the difference was not statisticcally significant $(\mathrm{p}=0.0525)$.

\subsection{Circumeferential Dye Penetration Test}

Statistical analysis indicated no significant differences ( $p$ $>0.05$ ) between $\mathrm{R} / \mathrm{E}$ and $\mathrm{G} / \mathrm{P}$ at each root canal level except for the 5.0, 5.7, and $6.0 \mathrm{~mm}$ level, where GP/PCS performed statistically better than R/E. As shown in Figure 4 the mean GP/PCS leakage scores were lower than the corresponding $\mathrm{R} / \mathrm{E}$ values at almost all distances from the apex although differences were not statistically significant. In the most coronal sections of the R/E group a slightly reduced dye penetration with respect to the GP/PCS samples was evident, although the differences were not statistically significant.

\section{DISCUSSION}

The aim of this study was to use the fluid filtration and dye leakage tests to compare the sealing properties of a resin-based adhesive root canal obturating material (Resilon/Epiphany) to gutta-percha/zinc-oxide eugenolate sealer (Pulp Canal Sealer EWT), the current gold standard for endodontic filling materials.
Several methods exist to evaluate the sealing ability of root canal sealers. Most widespread methods to evaluate the dye penetration along the root canal consist of linear measurements following the tooth clearing or sections of the specimen along the main root canal axis [33].

During this study, specimens were sectioned perpendicular to the long axis of the root and the circumferential interfaces between the root canal walls and the filling material were examined and scored for dye penetration at the upper and the lower surface of each section. This enabled partial quantification of the three-dimensional extent of dye penetration and to obtain more reliable measurements.

The fluid transport model proposed by Wu et al. [31] offers several advantages over more commonly used techniques of assessing leakage. It has been suggested that the fluid transport model is both highly reproducible and more sensitive than dye penetration for the detection of full-length voids along the root canal [34]. Because this method does not destroy the samples, it is possible to obtain measurements of microleakage from the same specimens at intervals over extended periods [35], or other tests may be successively performed on the same specimens. On the other hand, the fluid filtration technique, is not able to discern the root canal level at which the microleakage is located. As an example, consider a material able to perfectly seal the coronal millimeter of the root canal but which completely fails to seal the rest of the canal. The fluid filtration results would indicate a perfect seal. In the results of the current study this is demonstrated by the absence of any fluid movement through the negative control group specimens in which the hollow roots were sealed only at the apex with wax and nail varnish coating.

Although the dye leakage test is not reliable or sensitive enough to effectively assess the sealing properties of

\section{FLUID FILTRATION TEST}

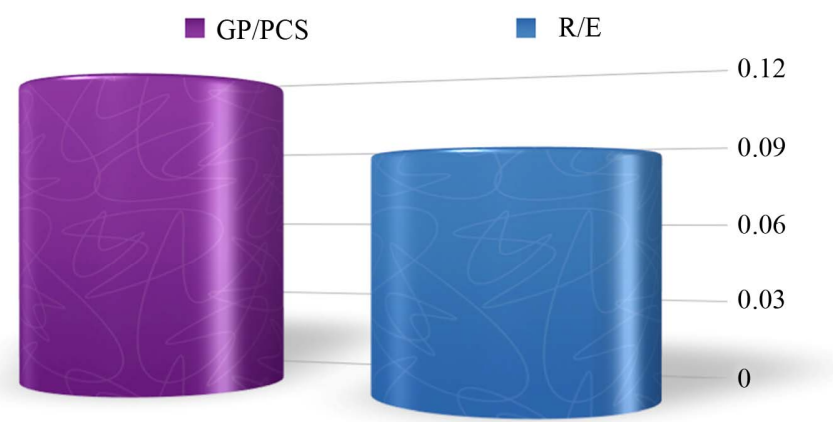

\begin{tabular}{|l|l|l|l|l|l|}
\hline & Median & Minimum & Lower Quartile & Upper Quartile & Maximum \\
\hline GP/PCS & 0.113 & 0.028 & 0.057 & 0.141 & 0.226 \\
\hline R/E & 0.085 & 0 & 0.057 & 0.113 & 0.170 \\
\hline
\end{tabular}

Figure 3. Fluid filtration test results. Values are expressed in $\mu \mathrm{L} \cdot \mathrm{min}^{-1}$. 


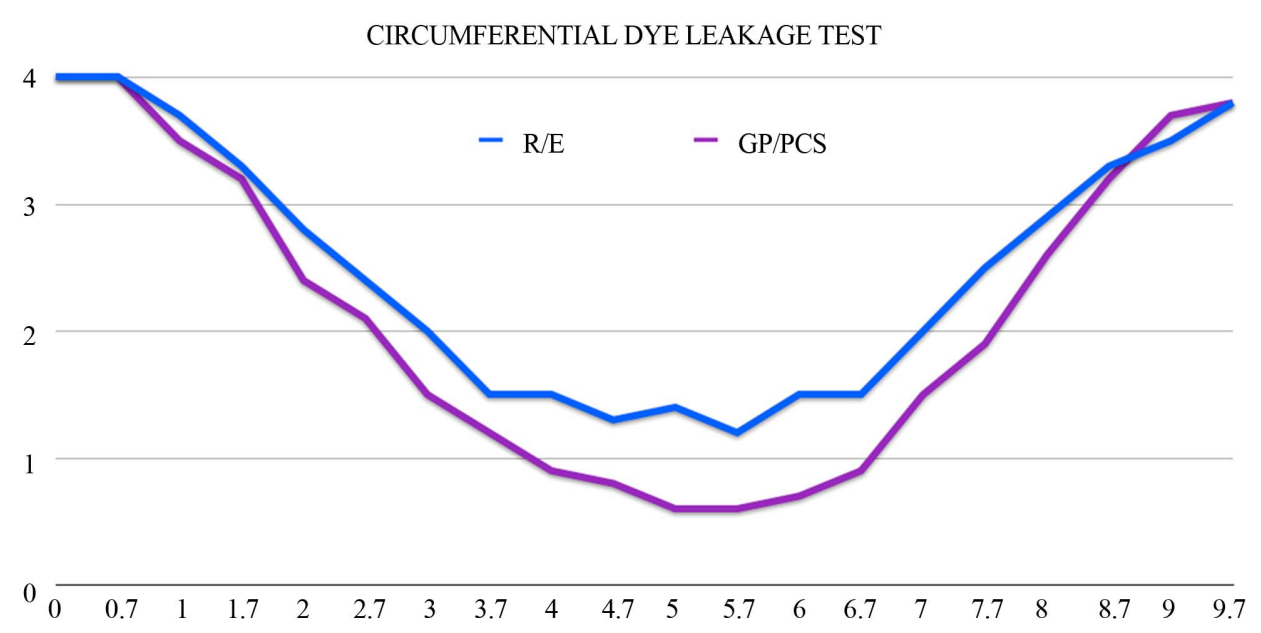

Figure 4. Mean circumferential dye penetration scores of Resilon/Epiphany and gutta-percha/Pulp Canal Sealer groups at any top and bottom level of sections. The graphs show how the mean circumferential dye penetration scores were always lower for the GP/PCS group except in the last coronal millimiter where R/E group performed slightly better than GP/PCS group.

an endodontic filling material, Pitout et al. [33] have already reported the use of a dye leakage test to corroborate results of a bacterial leakage study. The present study is focused on a combined analysis of fluid filtration and dye leakage results not only to evaluate the extension of R/E and GP/PCS microleakage, but also to locate areas of more extensive leakage.

The results of both the fluid filtration test and the dye leakage test indicate that there are no statistically significant differences both in the amount of fluid leakage and in the microleakage distribuition between $\mathrm{R} / \mathrm{E}$ and GP/PCS. The few statistical significances found during dye leakage testing in the middle portion of the root canals were not convincing enough conclude in favour of either method.

The current results are in agreement with the findings of studies using similar laboratory [36-38]. In these studies, an epoxy resin based sealer was used for filling the root canals. On the contrary, other fluid filtration studies demonstrated better sealing properties of Resilon/Epiphany combination respect to gutta-percha/epoxy resin based sealer although all of them experienced some degree of leakage [8,39-41]. However, even the comparison between fluid filtration studies is made difficult by multiple variable such as the use of different irrigants, sealers, condensation techniques, testing pressures or storage time.

The results of the present study are consistent with those of several studies with bacterial leakage model, which have found no enhanced sealing properties of Resilon/Epiphany as compared with other filling materials [33,42-44].

Nevertheless, Shipper et al. [16-19] with two studies based on a bacterial leakage model, compared lateral and vertical condensations of gutta-percha with AH26 to lateral and vertical condensations of Resilon/Epiphany. They found the Resilon/Epiphany leaked significantly less than the gutta-percha groups.

The periapical inflammatory response to microbial innoculation of dog roots filled with gutta-percha with AH26 versus Resilon/Epiphany indicated that Resilon provided superior apical sealing in dogteeth in vivo [20]. In the above three studies $[16,19,20]$ note that smear layer was not removed.

Cobankara et al. [45] showed significantly more leakage if the smear layer was not removed compared to being removed when they studied two sealers (not Resilon/Epiphany).

The formation of the monoblock claimed by the manufacturers of Resilon/Epiphany has been questioned by many authors [46-48]. While the goal of creating a monoblock of material between a root canal filling material and a sealer certainly does have merit [12], this goal may be prevented by various weak links in the two filling systems. In gutta-percha-filled canals, the weak link occurs between the gutta-percha and the sealer. Unlike gutta-percha specimens, the weak link in Resilon-filled root canals was the sealer-dentin interface [49].

A study by Tay et al. [49] using the transmission electron microscopy has shown the presence of silver deposits along the sealer-hybrid layer interface in EpiphanyResilon combination, and between the $\mathrm{AH}$ Plus sealer and gutta-percha. Authors also concluded that the quality of apical seal achieved with Epiphany-Resilon combination is not superior to AH Plus gutta-percha combination.

Perdigao et al. [50] found evidence of hybrid layers with adhesive materials but also reported areas of interfacial separation. They stated that despite the hybridiza- 
tion of resin-filling materials, a tight seal is difficult to achieve because of the complex anatomy and mechanical challenges such as polymerization shrinkage and unfavourable $\mathrm{C}$-factor inside the root canals. Bouillaguet et al. [51] reported that $\mathrm{C}$-factors in post spaces may exceed 200, compared to values between 1 and 5 in intracoronal restoration. Tay et al. [48] estimated that in a $20 \mathrm{~mm}$ long root canal the adhesive filling procedure with a 25 $\mu \mathrm{m}$ adhesive sealer thickness the theoretical C-factor could reach 954 .

Many authors have suggested factors that could negatively influence adhesion of methacrylate-based root canal sealers to the root dentinal walls, for instance removal of the smear layer, diffusion of the primer, moisture control, oxygen polymerization inhibition, and high resin-based sealer shrinkage. The results of microshear bond tests [40,49,52] and push-out tests [53] have demonstrated that the bonding of Resilon to Epiphany is weak (1 - $3 \mathrm{MPa})$.

Strengthening this last issue Onay et al. [37] also demonstrated that both the AH Plus/gutta-percha combination and the Epiphany/guttapercha combination had higher sealing ability than the Epiphany sealer and Resilon core combination suggesting that the Resilon core material, rather then the methacrylate-based sealer, could represent the weak point in the Resilon/Epiphany system.

The results of the present study confirm the absence of a monoblock seal. The presence of some amount of leakage and above all the presence of deep dye penetration both coronally and apically in both experimental groups suggest the lack of a tight and continuous seal along the root canal.

It should also be pointed out that, although the present study focused on Resilon/Epiphany sealing abilities at time 0 , several studies have already demonstrated the weakening of Resilon/epiphany seal even after relatively short storage periods due to degradation of adhesive interface $[8,30,43,54]$ and enzymatic degradation of polycaprolactone [10,49,55-57].

\section{CONCLUSION}

Under the experimental conditions of this study, Resilon/Epiphany sealed root canals as well as Guttapercha/Pulp Canal Sealer. Short-term evaluations suggest that a monoblock seal is not being achieved.

\section{ACKNOWLEDGEMENTS}

Authors would like to thanks Mr. Massimo Tolu for his precious technical support.

\section{REFERENCES}

[1] Bergenholtz, G. (1974) Microorganisms from necrotic pulp of traumatized teeth. Odontologisk Revy, 25, 347358.

[2] Kakehashi, S., Stanley, H. and Fitzgerald, R. (1965) The effect of surgical exposure of dental pulps in ger-free and conventional laboratory rats. Oral Surgery Oral Medicine Oral Pathology Oral Radiology and Endodontology, 20, 340-349.

[3] Moller, A.J., Fabricius, L., Dahlen, G., Ohman, A.E. and Heyden, G. (1981) Influence on periradicular tissues of indigenous oral bacteria and necrotic pulp tissue in monkeys. Scandinavian Journal of Dental Research, 89, 475484.

[4] Byström, A. and Sundqvist, G. (1983) Bacteriological evaluation of the effect of 0.5 percent sodium hypochlorite in endodontic therapy. Oral Surgery Oral Medicine Oral Pathology Oral Radiology and Endodontology, 55, 307-312.

[5] Byström, A. and Sundqvist, G. (1985) The antibacterial action of sodium hypochlorite and EDTA in 60 cases of endodontic therapy. International Endodontic Journal, 18, $35-40$.

http://dx.doi.org/10.1111/j.1365-2591.1985.tb00416.x

[6] Dalton, B.C., Ørstavik, D., Phillips, C., Pettiette, M. and Trope, M. (1998) Bacterial reduction with nickel-titanium rotary instrumentation. Journal of Endodontics, 24, 763767. http://dx.doi.org/10.1016/S0099-2399(98)80170-2

[7] Shuping, G.B., Ørstavik, D., Sigurdsson, A. and Trope, M. (2000) Reduction of intracanal bacteria using nickel-titanium rotary instrumentation and various medications. Journal of Endodontics, 26, 751-755. http://dx.doi.org/10.1097/00004770-200012000-00022

[8] Schilder, H. (1967) Filling root canals in three dimensions. Dental Clinics of North America, 11, 723-744.

[9] Khayat, A., Lee, S.J. and Torabinejad, M. (1993) Human saliva penetration of coronally unsealed obturated root canals. Journal of Endodontics, 19, 458-461. http://dx.doi.org/10.1016/S0099-2399(06)80533-9

[10] Madison, S. and Wilcox, L.R. (1988) An evaluation of coronal microleakage in endodontically treated teeth. Part III. In vivo study. Journal of Endodontics, 14, 455-458. http://dx.doi.org/10.1016/S0099-2399(88)80135-3

[11] Swanson, K. and Madison, S. (1987) An evaluation of coronal microleakage in endodontically treated teeth. Part I. Time Periods. Journal of Endodontics, 13, 56-59. http://dx.doi.org/10.1016/S0099-2399(87)80155-3

[12] Torabinejad, M., Ung, B. and Kettering, J.D. (1990) In vitro bacterial penetration of coronally unsealed endodontically treated teeth. Journal of Endodontics, 16, 566569. http://dx.doi.org/10.1016/S0099-2399(07)80198-1

[13] Hovland, E.J. and Dumsha, Y.C. (1986) Leakage evaluation in vitro of the root canal sealer Sealapex. International Endodontic Journal, 19, 21-28.

[14] Wu, M.K. and Wesselink, P.R. (1993) Endodontic leakage studies reconsidered, part 1: methodology, application and relevance. International Endodontic Journal, 26, 37-43. http://dx.doi.org/10.1111/j.1365-2591.1993.tb00540.x

[15] Lee, K.W., Williams, M.C., Camps, J.J. and Pashley, D.H. (2002) Adhesion of endodontic sealers to dentin and gutta-percha. Journal of Endodontics, 28, 684-688. 
http://dx.doi.org/10.1097/00004770-200210000-00002

[16] Shipper, G. and Trope, M. (2004) In vitro microbial leakage of endodontically treated teeth using new and standard obturation techniques. Journal of Endodontics, 30, 154-158. http://dx.doi.org/10.1097/00004770-200403000-00007

[17] Amass, W., Amass, A. and Tighe, B. (1998) A review of biodegradable polymers: Uses, current developments in the synthesis and characterization of biodegradable polyesters, blend of biodegradable polymers and recent advances in biodegradation studies. Polymer International, 47, 89-144.

http://dx.doi.org/10.1002/(SICI)1097-0126(1998100)47:2 $\leq 89::$ AID-PI86>3.0.CO;2-F

[18] Jia, W.T. and Alpert, B. (2003) Root canal filling material. US Patent No. 20030113686.

[19] Shipper, G., Ørstavik, D., Teixeira, F.B. and Trope, M. (2004) An evaluation of microbial leakage in roots filled with a thermoplastic synthetic polymer-based root canal filling material (Resilon). Journal of Endodontics, 30, 342347.

http://dx.doi.org/10.1097/00004770-200405000-00009

[20] Shipper, G., Teixeira, F.B., Arnold, R.R. and Trope, M. (2005) Periapical inflammation after coronal microbial inoculation of dogs roots filled with gutta-percha or resilon. Journal of Endodontics, 31, 91-96. http://dx.doi.org/10.1097/01.don.0000140569.33867.bf

[21] Teixeira, F.B., Teixeira, E.C.N., Thompson, J.Y. and Trope, M. (2004) Fracture resistance of roots endodontically treated with a new resin filling material. Journal of American Dental Association, 135, 646-652.

[22] Antonopoulos, K.G., Attin, T. and Hellwig, E. (1998) Evaluation of the apical seal of root canal fillings with different methods. Journal of Endodontics, 24, 655-658. http://dx.doi.org/10.1016/S0099-2399(98)80149-0

[23] Michailesco, P.M., Valcarel, J., Grieve, A.R., Levallois, B., Lerner, B. and Lerner, D. (1996) Bacterial leakage in endodontics: An improved method for quantification. Journal of Endodontics, 22, 535-539. http://dx.doi.org/10.1016/S0099-2399(96)80013-6

[24] Haikel, Y., Wittenmeyer, W., Bateman, G., Bentaleb, A. and Allemann, C. (1999) A new method for the quantitative analysis of endodontic microleakage. Journal of Endodontics, 25, 172-178.

http://dx.doi.org/10.1016/S0099-2399(99)80136-8

[25] Kaya, B.U., Kececi, A.D. and Belli, S. (2007) Evaluation of the sealing ability of gutta-percha and thermoplastic synthetic polymer-based system along the root canals trough the glucose penetration model. Oral Surgery Oral Medicine Oral Pathology Oral Radiology and Endodontology, 104, 66-73.

[26] Karagöz-Kücükay, I. and Bayirli, G. (1994) An apical leakage study in the presence and absence of the smear layer. International Endodontic Journal, 27, 87-93. http://dx.doi.org/10.1111/j.1365-2591.1994.tb00236.x

[27] Camps, J. and Pashley, D. (2003) Reliability of the dye penetration studies. Journal of Endodontics, 29, 592-594. http://dx.doi.org/10.1097/00004770-200309000-00012

[28] Ramachandran Nair, P.N. (1997) Apical periodontitis: A dynamic encounter between root canal infection and host response. Periodontology, 13, 121-148. http://dx.doi.org/10.1111/j.1600-0757.1997.tb00098.x

[29] Pommel, L., Jacquot, B. and Camps, J. (2001) Lack of correlation among three methods for evaluation of apical leakage. Journal of Endodontics, 27, 347-350. http://dx.doi.org/10.1097/00004770-200105000-00010

[30] Orucoglu, H., Sengun, A. and Yilmaz, N. (2005) Apical leakage of resin based root canal sealers with a new computerized fluid filtration meter. Journal of Endodontics, 31, 886-890. http://dx.doi.org/10.1097/01.don.0000164134.79052.b3

[31] Wu, M.K., De Gee, A.J., Wesselink, P.R. and Moorer, W.R. (1993) Fluid transport and bacterial penetration along root canals fillings. International Endodontic Journal, 26, 203-208. http://dx.doi.org/10.1111/j.1365-2591.1993.tb00560.x

[32] Galvan, R.R., West, L.A., Liewehr, F.R. and Pashley, D.H. (2002) Coronal microleakage of five materials used to create an intracoronal seal in endodontically treated teeth. Journal of Endodontics, 28, 59-61. http://dx.doi.org/10.1097/00004770-200202000-00002

[33] Pitout, E., Oberholzer, T.G., Blignaut, E. and Molepo, J. (2006) Coronal leakage of teeth root filled with guttapercha or resilon root canal filling material. Journal of Endodontics, 32, 879-881. http://dx.doi.org/10.1016/j.joen.2006.02.004

[34] Wu, M.K., De Gee, A.J. and Wesselink, P.R. (1994) Fluid transport and dye penetration along root canal fillings. International Endodontic Journal, 27, 233-238. http://dx.doi.org/10.1111/j.1365-2591.1994.tb00261.x

[35] Wu, M.K., De Gee, A.J. and Boersma, J. (1995) A 1-year follow up study on leakage of four root canal sealers at different thickness. International Endodontic Journal, 28, 185-189. http://dx.doi.org/10.1111/j.1365-2591.1995.tb00297.x

[36] Biggs, S.G., Knowles, K.I., Ibarrola, J.L. and Pashley, D.H. (2006) An in vitro assessment of the sealing ability of Resilon/Epiphany using fluid filtration. Journal of Endodontics, 32, 759-761.

http://dx.doi.org/10.1016/j.joen.2005.08.013

[37] Onay et, E.O., Ungor, M. and Orucoglu, H. (2006) An in vitro evaluation of the apical sealing ability of a new resin based root canal obturation system. Journal of Endodontics, 32, 976-978. http://dx.doi.org/10.1016/j.joen.2006.05.013

[38] Paqué, F. and Sirtes, G. (2007) Apical sealing ability of Resilon/Epiphany versus gutta-percha/AH Plus: Immediate and 16-months leakage. Internationa Endodontic Journal, 40, 722-729.

[39] Sagsen, B., Kahraman, Y. and Orucoglu, H. (2006) Evaluation of microleakage of roots filled with different techniques with a computerized fluid filtration technique. Journal of Endodontics, 32, 1168-1170. http://dx.doi.org/10.1016/j.joen.2006.07.016

[40] Tunga, U. and Bodrumlu, E. (2006) Assessment of the sealing ability of a new root canal obturation material. Journal of Endodontics, 32, 876-878. http://dx.doi.org/10.1016/j.joen.2006.02.005 
[41] Wedding, J.R., Brown, C.E., Legan, J.J., Moore, B.K. and Vail, M.M. (2007) An in vitro comparison of microleakage between Resilon and Gutta-perhca with a fluid filtration model. Journal of Endodontics, 33, 1447-1449. http://dx.doi.org/10.1016/i.joen.2007.08.021

[42] Baumgartner, G., Zehnder, M. and Paque, F. (2007) Enterococcus faecalis type strain leakage through root canals filled with Gutta-Percha/AH plus or Resilon/Epiphany. Journal of Endodontics, 33, 45-47. http://dx.doi.org/10.1016/j.joen.2006.08.002

[43] De-Deus, G., Audi, C., Murad, C., Fidel, S. and Fidel, R.A. (2007) Sealing ability of oval-shaped canals filled using the system B heat source with either Gutta-percha or Resilon: An ex vivo study using a polymicrobial leakage model. Oral Surgery Oral Medicine Oral Pathology Oral Radiology and Endodontology, 104, 114-119. http://dx.doi.org/10.1016/j.tripleo.2007.03.028

[44] Munoz, H.R., Saravia-Lemus, A., Florian, W.E. and Lainfiesta, J.F. (2007) Microbial leakage of Enterococus faecalis after post space preparation in teeth filled in vivo with realseal versus gutta-percha. Journal of Endodontics, 33, 673-675. http://dx.doi.org/10.1016/j.joen.2007.02.007

[45] Cobankara, F.K., Adanir, N. and Belli, S. (2004) Evaluation of the influence of the smear layer on the apical and coronal sealing abilites of two sealers. Journal of Endodontics, 30, 406-409. http://dx.doi.org/10.1097/00004770-200406000-00007

[46] Raina, R., Loushine, R.J., Weller, N., Tay, F.R., Pashley, D.H. (2007) Evaluation of the quality of the apical seal in Resilon/Epiphany and Gutta-Percha/AH plus-filled root canals by using a fluid filtration approach. Journal of Endodontics, 33, 944-947. http://dx.doi.org/10.1016/j.joen.2007.05.003

[47] Tay, F.R., Hiraishi, N. and Pashley, D.H. (2006) Bondability of Resilon to a methacrylate based root canal sealer. Journal of Endodontics, 32, 133-137. http://dx.doi.org/10.1016/j.joen.2005.10.026

[48] Tay, F.R., Loushine, R.J., Lambrechts, P., Weller, N. and Pashley, D.H. (2005) Geometric factors affecting dentin bonding in root canals: A theoretical modeling approach. Journal of Endodontics, 31, 584-589. http://dx.doi.org/10.1097/01.don.0000168891.23486.de

[49] Tay, F.R., Loushine, R.J., Weller, R.N., Kimbrough, W.
F., Pashley, D.H., Mak, Y.F., Lai, C.N., et al. (2005) Ultrastructural evaluation of the apical seal in roots filled with a polycaprolactone-based root canal filling material. Journal of Endodontics, 32, 514-519. http://dx.doi.org/10.1097/01.don.0000152298.81097.b7

[50] Perdigao, J., Lopes, M.M. and Gomes, G. (2007) Interfacial adaptation of adhesive materials to root canal dentin. Journal of Endodontics, 33, 259-263. http://dx.doi.org/10.1016/i.joen.2006.10.002

[51] Bouillaguet, S., Troesch, S., Wataha, J.C., Krejci, I., Meyer, J.M. and Pashley, D.H. (2003) Microtensile bond strength between adhesive cements and root canal dentin. Dental Materials, 19, 199-205. http://dx.doi.org/10.1016/S0109-5641(02)00030-1

[52] Hiraishi, N., Papacchini, F. and Loushine, R.J. (2005) Shear bond strength of Resilon to a methacrylate-based root canal sealer. International Endodontic Journal, 38, $753-763$. http://dx.doi.org/10.1111/j.1365-2591.2005.01012.x

[53] Gesi, A., Raffaelli, O., Goracci, C., Pashley, D.H., Tay, F.R. and Ferrari, M. (2005) Interfacial strength of Resilon and gutta-percha to intraradicular dentin. Journal of Endodontics, 31, 809-813. http://dx.doi.org/10.1097/01.don.0000158230.15853.b7

[54] De-Deus, G., Namen, F. and Galan Jr., J. (2008) Reduced long-term sealing ability of adhesive root fillings after water-storage stress. Journal of Endodontics, 34, 322325. http://dx.doi.org/10.1016/j.joen.2007.12.014

[55] Gan, Z., Liang, Q., Zhang, J. and Jing, X. (1997) Enzymatic degradation of poly(_-caprolactone) film in phosphate buffer solution containing lipases. Polymer Degradation and Stability, 56, 209-213. http://dx.doi.org/10.1016/S0141-3910(96)00208-X

[56] Hayashi, T., Nakayama, K., Mochizuki, M. and Masuda, T. (2002) Studies on biodegradable poly(hexano-6-lactone) fibers. Part 3. Enzymatic degradation in vitro (IUPAC Technical Report). Pure and Applied Chemistry, 74, 869-880. http://dx.doi.org/10.1351/pac200274050869

[57] Lefèvre, C., Tidjani, A., Vander Wauven, C. and David, C. (2002) The interaction between microorganisms and substrate in the biodegradation of polycaprolactone. Journal of Applied Polymer Science, 83, 1334-1340. http://dx.doi.org/10.1002/app.10124 